\title{
Histochemical Demonstration of Testicular $\beta$-Glucuronidase during the Reproduction Cycle of Indian Major Carp, Labeo rohita
}

\author{
Arun M. Chilke* \\ Division of Toxicology and Biomonitoring, Department of Zoology, Shree Shivaji Arts, Commerce and Science College, Rajura-442905, India
}

\begin{abstract}
In the present work, an attempt has been made to demonstrate the $\beta$-glucuronidase activity in the testes of Indian major carp, Labeo rohita during its reproductive cycle. In the resting phase, spermatogonia exhibit the granular staining; however in the seminiferous lobules, both the diffused and granular reaction was observed. During the preparatory phase, staining is noted in the spermatogonia, spermatocytes and with some increased activity in the interstitial cells. During prespawning phase, enzyme intensity increases which indicates hormonal dependency of this enzyme because during this stage proliferation of all spermatogenic stages takes place. This enzyme may have a role in cell proliferation and growth. Hormonal dependency is further substantiated. During spawning phase, interstitial cells which are implicated in hormone synthesis are intensely stained. Spermatids show moderate and intense enzyme activity at this phase. In the spawning phase, spermatozoa do not show any enzyme activity but broken wall and interstitial or Leydig cells show intense staining. During postspawning phase, the enzyme activity in the testes increases which may be due to increase in the lysosomal activity required for the degeneration of testes. Enzyme activity is not detected in the Sertoli cells during the entire reproductive cycle of $L$. rohita.
\end{abstract}

Keywords: Histochemistry; $\beta$-Glucuronidase; Testes; Carp

\section{Introduction}

It is a first attempt in an Indian major carp to demonstrate the $\beta$-glucuronidase activity during the reproductive cycle. However, no literature is available in this regard. $\beta$-Glucuronidase is an important enzyme which is known to play a role in carbohydrate metabolism. This enzyme was reported to remain active even at $60^{\circ} \mathrm{C}$ at $\mathrm{pH}-4.5$ $[2,3]$. It is an acid hydrolase and in Labeo rohita, the enhanced enzyme activity was reported at $\mathrm{pH}-5[2,3]$. Some authors have suggested its role in the testes of many vertebrates [6,8,9]. Males and Turkington [8] suggested magnitude of changes in $\beta$-glucuronidase during the spermatogenesis of rat. According to them, $\beta$-glucuronidase decreased five fold during development from the spermatogonial stage to full maturity. They further suggested that the developmental change in this enzyme depends upon hypophyseal function.

\section{Materials and Methods}

Male Labeo rohita was purchased throughout the year from Ambazari tank in Nagpur located very close to University Campus. Live fish was carried to the laboratory in polythin bag containing water. Total body weight was measured. Fish was perfused with icecold $0.01 \mathrm{M}$ phosphate buffer saline (PBS), pH-7.45 after providing anesthesia with intramuscular injection. Both the testes were removed and weighed for gonadosomatic index (GSI). One testis was fixed in Bouins fixative for histology and other one in $10 \%$ Neutral buffer formalin (NBF) for enzymorphology. $10 \mu \mathrm{m}$ thick sections of testes were cut on cryostat (Leica) at $-20^{\circ} \mathrm{C}$ and the sections were spread on slide treated with adhesive glycerol jelly.

$11 \mathrm{mg}$ Naphthol-AS-BI- $\beta$-D-glucuronic acid (Sigma) was dissolved in $0.05 \mathrm{M}$ Sodium carbonate and then diluted to $100 \mathrm{ml}$ with $0.1 \mathrm{M}$ acetate buffer ( $\mathrm{pH}-4.5$ ). This stock solution was preserved in the refrigerator at $4^{\circ} \mathrm{C}$. It was then diluted with $0.1 \mathrm{M}$ acetate buffer $(\mathrm{pH}-$ 4.5) to get solutions of variable molarities. It was observed that $1 \times 10^{-4} \mathrm{M}$ substrate solution gives the best result.

Immediately, prior to incubation, $0.5 \mathrm{ml}$ solution of sodium nitrate was added to $0.5 \mathrm{ml}$ acidic pararosaniline solution, mixed gently by inversion and allowed to stand for 5 minutes. Later, $38 \mathrm{ml}$ prewarmed deionized water, $5 \mathrm{ml}$ acetate buffer (0.1M; $\mathrm{pH}-4.5)$ and $5 \mathrm{ml}$ NaphtholAS-BI- $\beta$-D-glucuronic acid $\left(1 \times 10^{-4} \mathrm{M}\right)$ were added to get the final incubation solution. The formation of precipitation was rejected.

Sections were rinsed with cold $0.01 \mathrm{M}$ phosphate buffer saline (PBS), pH-7.45. Later, sections were slightly allowed to dry at room temperature. The sections were incubated for 90 minutes at $37^{\circ} \mathrm{C}$ and during this process the light contact was avoided. The sections were rinsed for 2-3 minutes in running water and then air dried for 15 minutes before counter staining in methylene green. The sections were rinsed in deionised water and then mounted in Glycerol jelly. Lastly, the microphotographs were taken.

\section{Results and Discussion}

In Labeo rohita, the resting phase is of three months (November to January) duration. During this phase, primary spermatogonia are dominant near the wall of testicular lobules. Spermatogonial cytoplasm exhibited granular $\beta$-glucuronidase activity, while both the granular and diffuse intense activity were seen in the testicular lobules (Figure 1). Granular staining indicated that the enzymes are stored in the lysosomes. However, the diffuse or disperse activity indicated that the enzyme has been deposited in the endoplasmic reticulum. Increased enzyme activity during resting phase in the primary spermatogonia and in testicular lobules suggested its role in the mitotic proliferation of spermatogonia from the germinal epithelium of testicular lobules. The preparatory phase lasted for two months (February and March). In this phase, enzyme activity was reduced as compared to the resting

*Corresponding author: Arun M. Chilke, Division of Toxicology and Biomonitoring, Department of Zoology, Shree Shivaji Arts, Commerce and Science College Rajura-442905, India, Tel: +917172 222215; E-mail: achilke@rediffmail.com

Received February 20, 2011; Accepted April 02, 2011; Published April 04, 2011

Citation: Chilke AM (2011) Histochemical Demonstration of Testicular $\beta$-Glucuronidase during the Reproduction Cycle of Indian Major Carp, Labeo rohita. J Cytol Histol 2:116. doi:10.4172/2157-7099.1000116

Copyright: (C) 2011 Chilke AM. This is an open-access article distributed under the terms of the Creative Commons Attribution License, which permits unrestricted use, distribution, and reproduction in any medium, provided the original author and source are credited. 
phase. Primary spermatogonia exhibited diffuse staining rather than granular. Secondary spermatogonia showed only diffuse staining and not granular one. In both- the primary spermatocytes and secondary spermatocytes, the enzyme activity was greatly reduced and was in slightly diffused form. However, no enzyme activity was seen in the spermatids (Figure 2). This reduction in the enzyme activity during the spermatogenesis from secondary spermatogonia to secondary spermatocytes suggested that the enzyme might have synthesized during the formation of primary spermatogonia and not in the spermatocytes.

Histochemically, further, the enzyme activity slightly increased during prespawning phase as compared to previous one (Figure 3). This phase was marked by proliferation of all the spermatogenic stages. Sudden increase of enzyme in this phase could implicate $\beta$-glucuronidase role in cellular proliferation, growth and differentiation. This is further

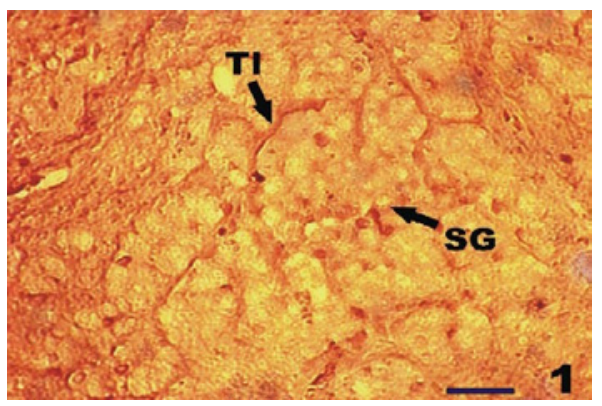

Figure 1: Germinal epithelium of the testicular lobules (TI) (arrow) and Spermatogonia (SG) showing diffuse and granular $\beta$-glucuronidase staining in resting phase of $L$. rohita $\mathrm{X} 200$.

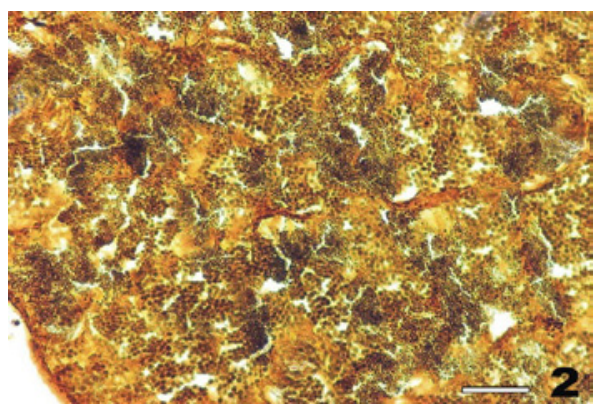

Figure 2: Moderate diffuse to granular staining of $\beta$-glucuronidase in spermatogenic stages of $L$. rohita during preparatory phase $\mathrm{X} 200$.

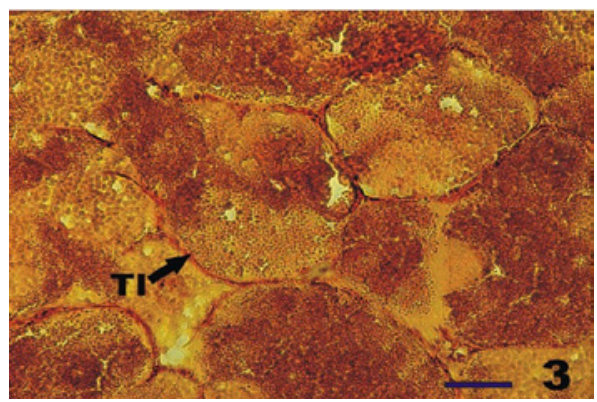

Figure 3: Intense diffuse staining of $\beta$-glucuronidase in the wall of testicular lobule (arrow) and in spermatogenic stages of $L$. rohita during prespawning phase X200.

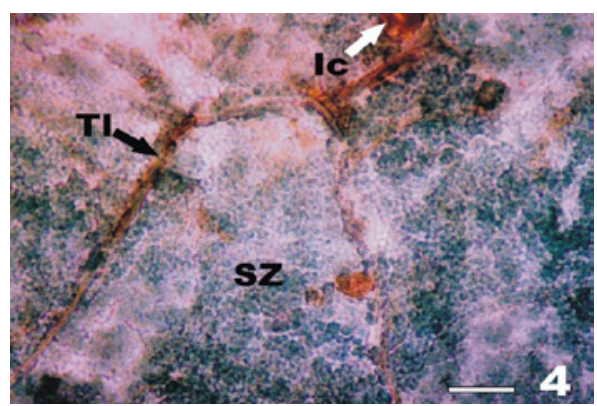

Figure 4: Intense staining of $\beta$-glucuronidase in the interstitial cells (Ic) and broken lobular wall in the testes (arrow) of $L$. rohita during spawning phase with no staining in the spermatozoa (SZ) X125.

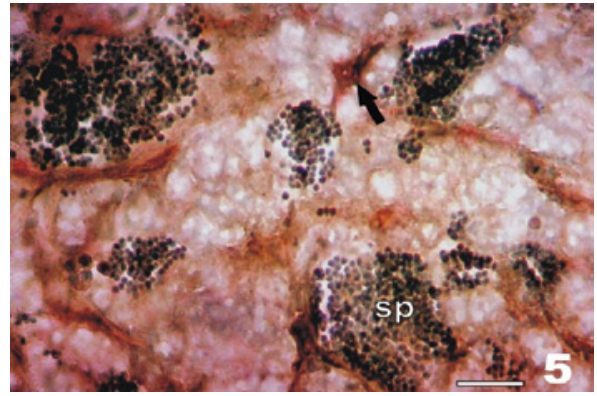

Figure 5: Increased intense diffuse staining of $\beta$-glucuronidase in the testis of $L$. rohita during postspawning phase $\mathrm{X} 125$.

supported by the fact that in the spawning phase, there was drastic fall in the enzyme content which was also minimum of the season. At this phase, maturation got completed and no other spermatogenic cells were visible. Seminiferous lobules were full of spermatozoa only and they were not stained at all with $\beta$-glucuronidase (Figure 5). Only the wall of interstitial cells was moderately stained. Gresik et al. [5] reported phagocytosis in the columnar epithelium cells in the spermatogenic cysts of Oryzias latipus, thus indicating involvement of lysosomes in it. In rat tissues, Fishman and Baker [4] reported moderate to intense staining for $\beta$-glucuronidase in seminiferous epithelium including Sertoli cells and interstitial cells but they have reported poor activity in spermatozoan tails. In $L$. rohita also, no staining was observed in spermatozoa. Moderate staining in the walls could be due to lytic processes because by the end of spawning phase, wall of the lobules break and sperms are released out. Hayashi and Fishman [6] also demonstrated $\beta$-glucuronidase in rat testis by employing the histochemical technique. Wrobel and Kuehnel $[9,10]$ reported the Leydig cells of several vertebrates viz. dogs, cats, pigs and goats form another principal site of $\beta$-glucuronidase localization. Varute [11] reported $\beta$-glucuronidase activity in seminiferous epithelium, Leydig cells and Sertoli cells of frog testis in seasonal breeding-hibernation cycle of Indian bull frog, Rana tigrina using both biochemical and histochemical techniques.

With evacuation of sperms at the end of spawning phase, testicular regression sets in. As spermatogenesis was initiated at the lobular wall in the post-spawning phase again, primary spermatogonia were visible which were positively stained by $\beta$-glucuronidase (Figure 5 ). In this phase, lobular walls also exhibited intense staining. Quantitatively, enzyme content was increased than in the spawning phase. It lowered down to its minimum in the next resting phase of the reproductive 
Citation: Chilke AM (2011) Histochemical Demonstration of Testicular $\beta$-Glucuronidase during the Reproduction Cycle of Indian Major Carp, Labeo rohita. J Cytol Histol 2:116. doi:10.4172/2157-7099.1000116

Page 3 of 3

cycle. In Tilapia mossambica testes, cysts in general showed granular $\beta$-glucuronidase activity, thus, indicating presence of lysosomes in them [7]. Breton et al. [1] reported presence of hydrolytic enzyme in the sperms of trout and carp, but in the sperms of T. mossambica, no $\beta$-glucuronidase activity was seen [7]. In L rohita also, no activity of $\beta$-glucuronidase was found in the spermatozoa. Kanase [7] reported on 5 different vertebrates from fish to mammals, concluded that in all of them, testicular $\beta$-glucuronidase contents were never maximum when testes were loaded with mature spermatozoa, whereas they were maximum in the post-breeding or post-copulatory period of testicular regression. In contrast to this, in L. rohita, maximum enzyme deposition was observed in prespawning phase and not in the post spawning one. Minimum activity was observed in spawning phase and there was increase in postspawning one but it was not highest of the season as reported for T. mossambica.

\section{Acknowledgement}

The author is very thankful to University Grant Commission, New Delhi for providing the Teachers Fellowship and also to the Head, Department of Zoology, Rashtrasant Tukdoji Maharaj Nagpur University, Nagpur for providing the laboratory facilities. Similarly, author would like to thank Prof. S.N. Shende, Department of English for editing the manuscript.

\section{References}

1. Breton B, Menezo Y, Billard R (1974) Demonstration of several enzymes in the sperm of the carp (Cyprinus carpio L.) and the trout (Salmo gaidneri Richardson) and in the coelomic fluid of the trout. C R Acad Sci Hebd Seances Acad Sci D 278: 1285-1288.
2. Chilke AM (2010) In situ kinetics of renal $\beta$-glucuronidase in teleost, Labeo rohita (Hamilton). Fish Physiol Biochem 36: 911-915.

3. Chilke AM (2010) Kinetic study of hepatic $\beta$-glucuronidase in Indian Major Carp, Labeo rohita (Hamilton). Fish Physiol Biochem 36: 1145-1149.

4. Baker JR, Fishman WH (1956) Cellular localization of beta-glucuronidase in rat tissues. J Histochem Cytochem 4: 570-587.

5. Gresik EW, Quirk JG, Hamilton JB (1973) A fine structural and histochemical study of the Leydig cell in the testis of the teleost, Oryzias latipes (Cyprinidontiformes). Gen Comp Endocrinol 20: 86-98.

6. Hayashi M, Fishman WH (1961) Enzymorphologic observation in the uterus and vagina of castrate rats receiving ovarian hormones. Acta Endocrinol (Copenh) 38: 107-120.

7. Kanase AA (1978) Beta-glucuronidase in reproductive organs of some vertebrates seasonal breeders. Ph.D. Thesis, Shivaji University, Kolhapur.

8. Males JL, Turkington RW (1971) Hormonal control of lysosomal enzymes during spermatogenesis of rat. Endocrinology 88: 578-588.

9. Wrobel VK, Kuhnel W (1967) On the histopathology of adenosine triphosphatase in the bovine endometrium during late follicular phase. Berl Munch Tierarztl Wochenschr 80: 25-56.

10. Wrobel KH, Kuhnel W (1968) Enzymatic histochemistry of the testis in domestic animals. I. Oxidoreductase in the testes of goat and pig. Berl Munch Tierarzt Wochenschr 81: 86-90

11. Varute AT (1971) Histoenzymorphology of beta-glucuronidase in spermatogenic epithelium, Leydig cells and Sertoli cells of frog testes in seasonal breeding hibernation cycle. Acta Histochem 41: 256-275. 